\title{
Hyperglycosylated resurfaced stabilized GP120 core as an immunogen elicits antibodies targeted at the CD4-binding site
}

\author{
K Dai', JC Boyington, W Shi, SD Schmidt, I Georgiev, D Lingwood, PD Kwong, JR Mascola, Z Yang, GJ Nabel \\ From AIDS Vaccine 2012 \\ Boston, MA, USA. 9-12 September 2012
}

\section{Background}

HIV-1 utilizes multiple mechanisms to evade immune surveillance. This has hindered the development of an effective vaccine. The CD4bs represents a highly conserved vulnerable site on HIV envelope that serves as an important target in HIV vaccine development. Novel concepts, such as resurfacing and glycan masking are some of the current approaches used to refocus the immune responses.

\section{Methods}

In this study, we used structural information of HIV gp120 core, together with the computer-assisted protein design tool to strategically add various glycosylation sites on the protein surface and create a panel of resurfaced stabilized core (RSC3)-based derivatives. The modified proteins were expressed in $293 \mathrm{~F}$ or $\mathrm{GnTi}(-/-)$ cells and purified by Nickel-affinity and gel-filtration chromatography. To verify the glycosylation sites and antigenic analysis, the purified proteins were subject to mass spectrometry and SDS PAGE analysis using a panel of welldefined monoclonal antibodies. The proteins with desirable antigenicity and well-tolerated glycan additions were tested for their immunogenicity in mice and NHPs.

\section{Results}

Two hyperglycosylated mutants containing five or six extra glycans (RS3.Y5 and RSC3. Y6.1) elicited CD4bs antibodies in significant quantities. Variant Y6.1 was further tested in the NHP model, in which Y6.1 elicited non-neutralizing CD4bs antibodies. In addition, a novel glycan mutant Y8.2_1 was developed based on Y6.1 by incorporating 3 extra glycans. Antigenic analysis indicated that the protein was able to eliminate the binding of non-neutralizing or less potent CD4bs antibodies such as b12 and b13, but still retain the binding capacities to potent CD4bs antibodies such as VRC01 and VRC-PG04.

\section{Conclusion}

It is now feasible to induce CD4bs antibodies by vaccination with immunogens that have exogenous N-linked glycans added to mask the "undesired" regions of the immunogen and have an exposed surface that targets the CD4bs epitope. Further optimization will be necessary to obtain CD4bs antibodies with neutralizing activity.

Published: 13 September 2012

doi:10.1186/1742-4690-9-S2-P23

Cite this article as: Dai et al:: Hyperglycosylated resurfaced stabilized GP120 core as an immunogen elicits antibodies targeted at the CD4binding site. Retrovirology 2012 9(Suppl 2):P23.

Submit your next manuscript to BioMed Central and take full advantage of:

- Convenient online submission

- Thorough peer review

- No space constraints or color figure charges

- Immediate publication on acceptance

- Inclusion in PubMed, CAS, Scopus and Google Scholar

- Research which is freely available for redistribution

Vaccine Research Center, NIAID, NIH, Bethesda, MD, USA 